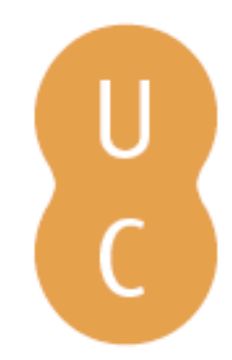

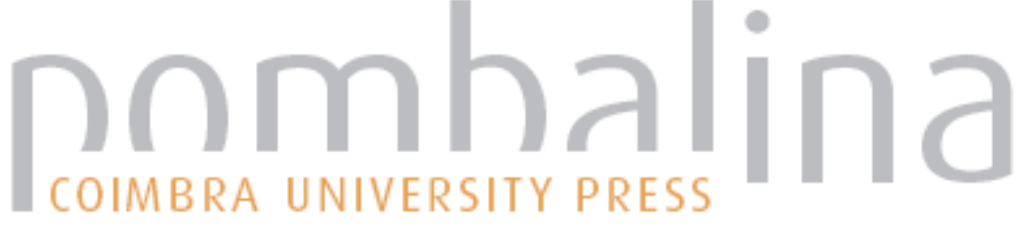

\section{A agonia da República Brasileira, 1899-1945}

Autor(es): $\quad$ Carneiro, Maria Luiza Tucci

Publicado por: Imprensa da Universidade de Coimbra

URL

persistente: URI:http://hdl.handle.net/10316.2/31143

DOI: $\quad$ DOI:http://dx.doi.org/10.14195/978-989-26-0497-8_13

Accessed : $\quad$ 26-Apr-2023 14:14:33

A navegação consulta e descarregamento dos títulos inseridos nas Bibliotecas Digitais UC Digitalis, UC Pombalina e UC Impactum, pressupõem a aceitação plena e sem reservas dos Termos e Condições de Uso destas Bibliotecas Digitais, disponíveis em https://digitalis.uc.pt/pt-pt/termos.

Conforme exposto nos referidos Termos e Condições de Uso, o descarregamento de títulos de acesso restrito requer uma licença válida de autorização devendo o utilizador aceder ao(s) documento(s) a partir de um endereço de IP da instituição detentora da supramencionada licença.

Ao utilizador é apenas permitido o descarregamento para uso pessoal, pelo que o emprego do(s) título(s) descarregado(s) para outro fim, designadamente comercial, carece de autorização do respetivo autor ou editor da obra.

Na medida em que todas as obras da UC Digitalis se encontram protegidas pelo Código do Direito de Autor e Direitos Conexos e demais legislação aplicável, toda a cópia, parcial ou total, deste documento, nos casos em que é legalmente admitida, deverá conter ou fazer-se acompanhar por este aviso.

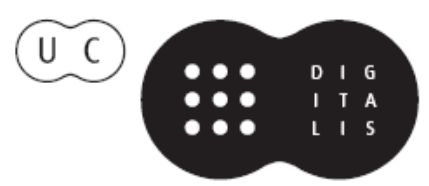


Armando Malheiro da Silva

Maria Luiza Tucci Carneiro

Stefano Salmi

Coordenação

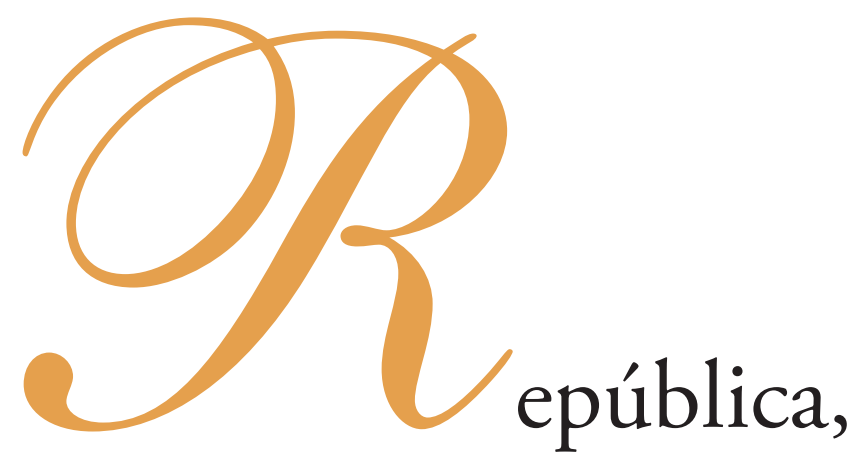

Republicanismo

e Republicanos

Brasil • Portugal • Itália 


\section{Maria Luiza Tucci Carneiro}

\section{A AGONIA DA REPÚBLICA BRASILEIRA, 1899-1945}

A República brasileira nasceu atrofiada pela censura e pela persistência de um pensamento intolerante. Pretendia ser moderna no seu liberalismo, mas nasceu sufocada pela índole territorialista das elites políticas que não conseguiam se desvencilhar do patrimonialismo e da estrutura anacrônica do sistema produtivo herdados dos tempos coloniais. Desde a sua proclamação em 15 de Novembro de 1889, a República foi sendo minada por práticas conservadoras e autoritárias que contrariavam o ideal de uma sociedade pluralista, distintas por diferentes etnias e posturas políticas. O ideário republicano, calcado no lema Ordem e Progresso, prestou-se ao longo do século xx, para encobrir interesses de grupos preocupados em perpetuar o monopólio do exercício do poder. Esta tensão se fez latente desde os primeiros anos da República cujo destino era disputado por proprietários rurais, camadas médias urbanas e militares; cada qual, respectivamente, distinto por seu paradigma: o modelo de República norte-americano, a fase jacobina da Revolução francesa e a versão positivista da República ${ }^{395}$. Apesar das propostas no plano dos direitos políticos e da cidadania, a Constituição de 1891 se limitou, a ratificar os preconceitos herdados do colonialismo e da Monarquia, aprimorando as estratégias ideológicas de exclusão social.

\footnotetext{
395 Sobre esta questão tratam: CARVALHO, José Murilo de - A Formação das Almas. O Imaginário da República no Brasil. São Paulo: Companhia das Letras, 1990; MAGALHÃES, Marcelo de Souza - "Repensando política e cultura no início da República: existe uma cultura política carioca”. In SOIHET, Rachel; BICALHO, Maria Fernanda Baptista; GOUVÊA, Maria de Fátima Silva (orgs.) - Culturas Políticas. Ensaios de História Cultural, História Política e Ensino de História. Rio de Janeiro: Mauad, 2005, pp. 285-303.
} 
Ao longo da trajetória republicana, os ideais de Liberdade, Igualdade e Fraternidade cooptados do Liberalismo e da Maçonaria foram esquecidos servindo de refrão para muitos políticos e intelectuais dedicados a diagnosticar os problemas brasileiro. Declarada em 1899, a República tornou-se "velha" e rançosa, atributos que nas décadas de 1930 e 1940, serviram para justificar o Governo autoritário de Getúlio Vargas. Responsabilizada pelos caos e pela desordem pública, a "Velha" foi descartada pelos revolucionários de 1930 que, liderados por Vargas, iriam propor a construção de uma nova Nação. A herança da Primeira República deveria ser esquecida, assim como deveria ter sido esquecida a herança monarquista, ambas responsabilizadas pelas desgraças e atrasos em que atingiam o Brasil.

\section{A República e o Povo}

Desde o início da era republicana, o Governo brasileiro investiu contra as discordâncias, agindo com violência e arbítrio. Com o fechamento do Congresso em 3 de Novembro de 1891 e a suspensão da liberdade de imprensa, fortalecia-se a idéia de consenso nacional que, ao longo de décadas, assumiria a força de mito. Compromissada com o passado colonial, a República chegou em nome da modernidade e identificada com os ideais civilizatórios. As elites políticas, por sua vez, se reestruturaram sem conseguir se desprender das suas tradicionais bases agrárias, fontes para recursos políticos e sociais. Assumiram o papel de elites modernas aproveitando-se da não-interferência das massas urbanas que, neste primeiro momento, mantinham-se afastadas das propostas revolucionárias do Liberalismo.

No dia da proclamação da República, o povo compareceu para "festejar" o acontecido, parecendo compactuar da apatia nacional cultuada pelo Estado. Esta postura - que não deve ser estendida de forma generalizada — serviu para reforçar, ao longo de décadas, a versão historiográfica de que a República havia sido proclamada "dentro da ordem, graças à índole do povo brasileiro". Observando a magnífica fotografia tirada por Marc Ferrez em 15 de Novembro de 1889, temos a impressão, realmente, de estarmos diante de uma grande parada na Praça da Aclamação (hoje, Praça da República) no Rio de Janeiro. Vestido para um dia de festa, o povo compareceu à praça para "assistir" ao fim 
do Império e o início da República ${ }^{396}$. Neste dia, o povo aparece como um mero espectador, desprovido do papel de agente revolucionário.

Praça da Aclamação(hoje Praça da República). Rio de Janeiro, 15 de Novembro de 1889.

Fotografia de Marc Ferrez. Biblioteca Nacional do Rio de Janeiro.

Segundo interpretação de José Murilo de Carvalho, em Os Bestializados: O Rio de Janeiro e a República que não foi, o povo não era tolo/bestializado, e sim "bilontra/esperto", vertente interpretativa que tem sido alvo de críticas em teses e dissertações em História ${ }^{397}$. Esperto ou apático, o povo não participou da conspiração articulada por um pequeno grupo militar que, no dia seguinte, nomeou-se Governo Provisório.

Registros iconográficos e correspondências pessoais, demonstram que a instauração da República foi para o povo, realmente, uma surpresa. Inúmeros são os indícios que o colocam como mero observador, distante da trama articulada nos bastidores da Monarquia. O Jornal do Commércio, um dia após a proclamação, comentou que a capital "despertou no meio de acontecimentos tão graves

${ }^{396}$ Segundo José Maria Bello, em seu livro História da República, editado em 1949, a atitude do povo foi de apatia e displicência. O fato da proclamação da República ser desprovida de grande participação do povo se deve, na sua opinião, ao fato desta ter assumido a forma de conspiração. Ver BELlO, José Maria - História da República, 1889-1954. São Paulo: Companhia Editora Nacional, 1972, p. 30 apud MAGALHÃES, Marcelo de Souza - op. cit., p. 286.

${ }^{397}$ CARVALHO, José Murilo de - Os Bestializados. O Rio de Janeiro e a República que não foi. São Paulo: Companhia das Letras, 1987. 
e tão imprevistos que as primeiras horas do dia foram de geral surpresa" ${ }^{398}$. Este mesmo semblante foi reforçado pelo Diário do Commércio que, ao comentar o "dia de ontem", considerou "nula e improfícua" a participação dos elementos civis que "só aparecem depois de realizado o movimento...":

"O dia de ontem foi de surpresas para a pacífica população industrial desta cidade.

Um ministério forte deposto sem combate, uma revolução militar triunfante, os corpos constitucionais arredados sem discussão alguma e o regime de governo atacado com êxito inesperado, são fatos que pareciam inexplicáveis se não se conhecesse a indole especial desta cidade, sempre disposta a aceitar os fatos consumados. (...). A revolução de ontem é filha unicamente das energias e espírito de classe dos militares, e foram os oficiais superiores que, passando-se para a causa democrática, a tornaram vencedora no momento"399.

O fotógrafo Militão de Azevedo (1837-1905), observou com muita sensibilidade o desenrolar desta cena política, conforme comentou em sua correspondência com Luiz Jablanski, ator de teatro residente em Paris:

“...Como deves ter sabido por telegrapho no dia 15 do corrente almocei monarchista e jantei republicano. Isto mostra que as coisas por aqui se fazem rápidas como o século que ellas representam: eletricidade e estrada de ferro. Julgo não haver na história Universal uma mudança radical de governo tão pacífica como esta. Das duas, uma: ou este povo não tem convicções nem oppiniões rezultado da convivência com a escravidão desde nascer, ou então é eminentemente philosófico e compreendeu que apenas houve mudança de rótulo que se fez e que costumam fazer mtos. Negociantes de vinhos: enchem as garrafas com a mesma pipa e põem-lhes rótulos differentes...”."400.

\footnotetext{
${ }^{398}$ Jornal do Commércio, Rio de Janeiro, 16 de Novembro de 1889.

399 Diário do Commércio, 16 de Novembro de 1889.

${ }^{400}$ Carta de Militão de Azevedo a Luiz Jablanski. São Paulo, Novembro de 1889 apud KOSSOY, Boris - Militão de Azevedo e a Documentação Fotográfica de São Paulo (1862-1887). Recuperação da Cena Paulistana através da Fotografia. Dissertação de Mestrado em Ciência apresentada à Escola Pós-Graduada de Ciências Sociais da Fundação Escola de Sociologia e Política de São Paulo, 1978, p. 87.
} 
A Gazeta da Tarde anunciou, naquele mesmo dia 15 de Novembro de 1889, que o Brasil entrara em nova fase, considerando "finda a Monarquia, passando a regime francamente democrático com todas as consequências da Liberdade". Atribuia ao exército essa "magna transformação" proclamada, no meio da maior tranqüilidade e com solenidade realmente imponente, que queria outra forma de governo". Conclamando os vencedores a legitimar a posse do poder com o selo da moderação, benignidade e justiça, dava "vivas" a Democracia e a Liberdade ${ }^{401}$. Aristides Lobo — jornalista inquieto e propagandista republicano manifestou suas impressões através de uma carta publicada no Diário Popular de São Paulo. A expressão "bestializado" atribuída ao povo serviu, anos mais tarde, para instigar o debate sobre a índole do brasileiro: "O povo assistiu àquilo bestializado (...), sem conhecer o que significava. Muitos acreditavam sinceramente estar vendo uma parada" ${ }^{402}$.

No dia seguinte à proclamação da República brasileira, um estadista liberal conhecido como Gladstone, pronunciou um discurso na cidade inglesa de Manchester. Impressionado com a apatia da população brasileira comentou:

"Sem a menor tentativa de violência, sem perturbação, (...) da ordem social, sem interromper o curso das transações comerciais por mais de 24 ou 48 horas, sem um tiro, sem prisões e sem efusão de sangue pois acredito que um só ferimento acidental faz exceção ao meu asserto — e tudo isso numa sociedade longingua, que se podia julgar de civilização atrasada, uma sociedade que lutou até há poucos dias, se é que ainda não luta de certo modo, contra a maldita e perniciosa escravidão, e onde a moral de todo o País deve ter sido consideravelmente retardada em seu desenvolvimento pela existência dessa deplorável instituição' ${ }^{\prime * 3}$.

${ }^{401}$ Gazeta da Tarde. Rio de Janeiro, 15 de Novembro de 1889.

${ }^{402}$ Aristides Lobo, jornalista e propagandista republicano, assumiu o cargo de Ministro do Interior no Governo Provisório. Carta de Aristides Lobo datada de 15 de Novembro de 1889, publicada no Diário Popular de São Paulo, São Paulo, 18 de Novembro de 1889 apud CARONE, Edgard - A Primeira República (1889-1930): Texto e Contexto. Rio de Janeiro: DIFEL, 1976, pp. 376-377.

${ }^{403}$ Discurso pronunciado por Gladistone, estadista liberal, em Manchester, 1899 apud MARTINS, Ana Luiza - República, Um Outro Olhar. São Paulo: Contexto. 
Na trama de uma "revolução passiva", o liberalismo foi administrado pelas tradicionais elites políticas e desgastado, num tempo de longa duração, pelo caudilhismo e pela violência institucionalizada. Lembramos aqui que o liberalismo, enquanto movimento político é, ao mesmo tempo, "uma direção de pensamento e de uma ação prática", retomando a afirmação de Manuel Suárez Cortina que estudou as tradições culturais do liberalismo espanhol entre 1808-1950. ${ }^{404}$ O povo, sem poder agir, ficou alijado do poder pois, segundo as elites, "não estava preparado para administrar o Liberalismo". Apelava-se para um conjunto de argumentos que, acionados pelos constituintes, expressavam a persistência de uma mentalidade excludente: o fato de apenas um décimo da população saber ler e escrever, a heterogeneidade e a debilidade das raças - lembrando sempre que o índio era bravio, porém "selvagem"; o preto africano "imbecíl e indolente" física e intelectual da mulher" ${ }^{\prime \prime 06}$.

Com base nestes argumentos, os constituintes de 1890-1891 procuraram forjar a imagem de que, até então, o povo estivera adormecido pelo "minotauro" da centralização imperial. "Agora - conforme ironizou Libero Badaró, deputado pelo estado de Minas Gerais - : a República está aceita, o que resta é entregá-la ao povo. [...]. Somos muito engraçados, senhores; lisonjeamos o povo de longe, mas quando temos de encontrar com ele, fugimos" ${ }^{\text {407. }}$.

${ }^{404}$ CORTINA, Manuel Suárez - "Las tradiciones culturales del Liberalismo español". In Las Máscaras de la Libertad. El Liberalismo Español, 1808-1950. Madrid: Marcial Pons Historia; Funación Práxedes Mateo Sagasta, 2003, p. 13.

${ }^{405}$ Retumda, ACCR, v. II, p.621 apud FERNANDES, Jorge Batista - "A Constituinte de 1890-1891. A institucionalização dos limites da cidadania”. Acervo. Revista do Arquivo Nacional, Rio de Janeiro, v.19, n 1-2, Jan/Dez 2006, p. 61.

${ }^{406}$ Expressivo desta postura, é o artigo $70^{\circ}$ do Congresso Constituinte que ratificou a exclusão dos direitos políticos dos clérigos, dos analfabetos, dos mendigos, dos praças de prete e, indiretamente, das mulheres. Lembramos aqui que o impedimento aos analfabetos vedando-lhes a participação política só foi liberado em 1985 e ratificado na Constituição de 1988. Desta forma, durante um século, a maioria da população brasileira ficou excluída do processo de ampliação da cidadania política.

${ }^{407}$ Badaró, ACCR, v. II, p.788 apud FERNANDES, Jorge Batista - op. cit., p. 63, 68. 


\section{Interpretando os Males da Nação}

$\mathrm{Na}$ ausência de um encontro entre intelectuais e povo, as elites deveriam assumir a sua obra civilizatória num movimento lento, equilibrado, quase imperceptível, sem rupturas radicais. Não lhes interessava criar conflitos abertos e nem romper com as elites territorialistas. Interessava sim o consenso e a aceitação das inovações, mas sem resistência. Nos momentos em que a resistência veio à luz, a repressão procurou amordaçá-la, calando as vozes dissidentes.

Constatamos que, no decorrer da primeira metade do século xx, a burguesia industrial e proprietária foi renunciando aos princípios universais do Liberalismo para ajustá-los as programas étnicos-políticos idealizados pelo Estado. Um conjunto de marcos institucionais são expressivos dessas práticas inibidoras da liberdade de expressão, do direito de ir e vir do cidadão, de igualdade diante da lei. Cada vez mais, as leis foram minando as possibilidades de manifestações políticas plurais, doutrinas e filosofias políticas que tinham como base a matriz liberal. Essa nova relação de forças impôs a redefinição dos ideais de liberdade, de justiça e ordem social conclamados pelos republicanos e pela grande imprensa nos dias imediatos à proclamação da República.

Ao impor limitações para as idéias e práticas liberais, as elites políticas demonstravam suas preocupações em reconhecer os direitos individuais e resolver "questões sociais" herdadas do colonialismo. Daí o lento processo de transição da ordem senhorial-escravocrata para um ordem social competitiva, como muito bem afirmou Luis Werneck Vianna. Assim chegou-se através da Abolição, na opinião de Vianna,

"à constituição de um mercado livre para a força de trabalbo sem rupturas no interior das elites, e a partir dela, à República, em mais um movimento de restauração de um dos pilares da economia colonial: o exclusivo agrário, que agora vai coexistir com um trabalhador formalmente livre, embora submetido a um estatuto de dependência pessoal aos senhores da terra"408.

${ }^{408}$ VIANNA, Luiz Werneck - "Caminhos e Descaminhos da revolução Passiva à Brasileira". Dados, Rio de Janeiro, IUPERJ, Vol. 39, n³, 1996. Texto elaborado a partir da transcrição da gravação da conferência de mesmo título. 
$\mathrm{Na}$ linguagem da época, tornou-se corrente a expressão "nada mais parecido com um conservador do que um liberal". Mas, mesmo assim, nos primeiros anos da República - como assim enfatizou Wilson Martins - tornou-se perigoso "não ser republicano". Retomo aqui os corajosos pronunciamentos pró e contra de Múcio Teixeira, em sua obra Novos Ideais que, na primeira edição de 1880, dizia-se essencialmente republicano; posição negada na segunda edição de 1891, na qual afirma:

"Fui republicano durante o Império; assiste-me, pois, o direito de declarar urbi et orbi que JÁ NÃO SOU REPUBLICANO; e ainda mais, que me considero um forasteiro na minha própria pátria, desde a funesta conjuração de não sei que dia de Novembro de 1889, que transformou o mais próspero dos países americanos nisto — que dizem ser república!'”209.

Assim como Múcio Teixeira, muitos outros se mostraram descontentes com a prática do novo ideário, como fica evidente em muitos impressos da República. Em nenhum momento, o Estado havia pensado em um projeto que partilhasse uma fatia de poder com a massa e, muito menos, que garantisse a inclusão social dos negros, ex-escravos. Ao contrário, formou-se uma frente limitadora da participação dos negros que, ainda hoje, sobrevivem com baixa renda e o grau mínimo de escolaridade. Legado da escravidão, legado da Monarquia, conservadorismo da República. ${ }^{410}$

Ao discurso oficial, somaram-se outras tantas narrativas a respeito do Estado Nação, inspirado no Liberalismo e cuja imagem foi sendo construída como resultado de um amálgama de elementos objetivos e subjetivos. Produzidas pelas elites política e intelectual preocupadas com a constituição de uma identidade nacional, essas narrativas se fizeram influenciadas pelas idéias deterministas, cientificistas e pelo positivismo. A partir de diferentes lugares de enunciação e distintos eixos de análise, buscavam interpretar os males da Nação que queria "ser moderna", como os Estados Unidos e a França.

${ }^{409}$ MARTINS, Wilson - História da Inteligência Brasileira, Vol. IV (1877-1896). São Paulo: Cultrix, 1978, p. 72-73; TEIXEIRA, Múcio - Novos Ideais. Rio de Janeiro: Tipografia (Imprensa) Nacional, 1880; 2 ed. 1891.

${ }^{410}$ Analiso esta questão no artigo "Negros Loucos, Loucos Negros", de minha autoria, in Revista USP. São Paulo, (18), Jul-Ago, 1993, pp. 144-150. 
Assim como no passado colonial — quando os cristãos-novos eram identificados como os males que atingiam o Reino de Portugal ${ }^{411}$ - os portugueses e os negros foram responsabilizados pelo atraso do País. Desde as últimas décadas do século XIX até o final do Estado Novo em 1945, os títulos das obras produzidas por renomados intelectuais brasileiros, por sí só, diziam para o quê vinham: Os Males do Presente e as Esperanças do Futuro, de Tavares Bastos (1837-1875)"412; A América Latina: Males de Origem, de Manoel Bonfim (1868-1932), de 1903 ${ }^{413}$. Anos mais tarde, Mário de Andrade, em Macunaíma, iria estabelecer um "diálogo em torno da preguiça como expressão do modo de ser dos brasileiros, além de reportar-se à força que a imagem da doença tinha na composição dos retratos do Brasil"14.

Favorecendo uma onda de lusofobia, um conjunto de argumentos insistiam no legado negativo da colonização, da escravidão e da Monarquia portuguesas que haviam mantido o Brasil na obscuridade. No ano de 1891, não faltaram manifestos e cartas anônimas acusando os imigrantes portugueses de favorecerem a restauração do Império ${ }^{415}$. Ao mesmo tempo, sentimentos nacionalistas e xenófobos, se prestavam para a construção da imagem de uma sociedade imaginada onde todos, num futuro próximo, estariam convivendo fraternalmente configurando uma espécie de irmandade política. Retomo aqui as palavras de Silvio Romero que, apesar de se pronunciar pela República - definida como "razoável e acertada" - mostrou-se hostil aos estrangeiros: "Nada de aglomerá-los às dezenas e centenas de milhares de uma só raça espalhados pelas quatro províncias do sul"116. Esta opinião, que não tem uma paternidade, persistiu em

${ }^{411}$ Para uma relação e análise destas obras anti-judaicas ver CARNEIRO, Maria Luiza Tucci - Preconceito Racial em Portugal e Brasil Colôni. Os Cristãos-Novos e a Questão da Pureza de Sangue. $3^{\text {a }}$ ed. São Paulo: Perspectiva, 2005.

${ }^{412}$ BASTOS, Tavares - Os Males do Presente e as Esperanças do Futuro. São Paulo: Companhia Editora Nacional, 1939 (Brasiliana, Vol. 151).

${ }^{413}$ BONFIM, Manoel - A América Latina: Males de Origem. Rio de Janeiro: Topbooks, 1993, p.173, (1 $1^{\mathrm{a}}$ ed.,1903)

${ }^{414}$ ANDRADE, Mário de - Macunaíuma: O Herói Sem Nenbum Caráter. $25^{\mathrm{a}}$ ed. Belo Horizonte: Itatiaia, 1988 (Coleção Buriti n 41); LIMA, Nísia Trindade; HOCHMAN, Gilberto - "Pouca saúde, muita saúva, os males do Brasil são... Discurso Médico-sanitário e interpretação do pais". Ciência \& Saúde Coletiva, 5 (2): 313-332, 2000, pp. 313-331.

${ }^{415}$ Este tema é amplamente desenvolvido, com base me fontes inéditas, por SACCHETTA, José Ariovaldo Ramos Mendes - Laços de Sangue. Privilégios e Intolerância Portuguesa no Brasil. Tese de Doutorado em História Social, FFLCH-USP, 2007

${ }^{416}$ Apud MARTINS, Wilson - op. cit., p. 268. 
vários outros escritos sobre os problemas brasileiros servindo para alimentar a tese do enquistamento. ${ }^{417}$

Instituía-se o sentimento de pertencimento como referência de conduta ideal que, endossado pelo programa étnico-político do Estado republicano, servia de medida contra a formação de quistos raciais, um dos males erosivos da Nação. Como elemento-símbolo do bom cidadão, estrangeiro ou nacional, pretendia-se que este, por sua índole, fosse ordeiro, pacífico e cristão. Neste perfil ideal não estava, certamente, incluído o negro interpretado como imbecil, indolente e debilitado por sua raça. Sob este foco, foram produzidos centenas de textos médicos higienistas que, nas primeiras décadas do século Xx, primaram pelas teses fatalistas de cunho biologizante. Ao diagnosticarem os males do Brasil, os higienistas somaram argumentos com os racialistas, preservando as matrizes do pensamento social e político brasileiro, intolerante na sua essência. Enumeradas as mazelas do Brasil, persistiu a ênfase na herança colonial - traço negativo enfatizado por Tavares Bastos e Manoel Bonfim - e na composição étnica da população ${ }^{418}$.

Através destas teorias e diagnósticos pseudo-cientificos, as elites políticas e intelectuais encontravam subsídios para manter a população afastada das esferas do poder, minimizando as possibilidades desta crescer enquanto agente social. Segundo o escritor Sílvio Romero, "nosso futuro estava comprometido pela ausência de uma feição característica original que não conformaria uma rala sociológica, carência irremediável que estaria a comprometer o seu caminho rumo à civilização". Como "tipo humano", o brasileiro "seria criado no futuro, estando em processo de constituição no terreno dos fatos: a miscigenação". Segundo Romero, "a miscigenação viria corrigir a morbidez da população, de vida curta, achacada e pesaros"; ..."dentro de dois ou três séculos, a fusão étnica estará talvez completa e o brasileiro, bem caracterizado"119. Ou seja, a retomada do elemento revolucionário, só seria possível mediante o desgaste dos fundamentos da ordem senhorial-escravocrata, e quando o liberalismo deixasse

\footnotetext{
${ }^{417}$ Retomo aqui as idéias defendidas por Oliveira Vianna, anos mais tarde, em sua clássica obra Raça e Assimilação. São Paulo: Companhia Editora Nacional, 1932 [Coleção Brasiliana].

${ }^{418}$ PRADO, Maria Emília - Memorial das Desigualdades: os Impasses da Cidadania no Brasil (1870-1902). Rio de Janeiro: Faperj/Revan, 2005; FERNANDES, Jorge Batista - "A Constituinte de 1890-1891. A Institucionalização dos Limites da Cidadania”. Acervo. Revista do Arquivo Nacional. Rio de Janeiro (19): 01/02, Jan.-Dez., 2006, pp. 55-68.
}

${ }^{419}$ ROMERO, Ś́lvio - História da Literatura Brasileira. 5ªed. Rio de Janeiro: José Olympio, 1953 
de ser vivenciado apenas no âmbito das suas elites. Enfim, "um destino a ser conquistado no futuro", segundo Florestan Fernandes ${ }^{420}$

República Amordaçada

Foi, no contexto da expansão da ordem burguesa, que o liberalismo foi reativado por alguns grupos que, até então, sobreviviam sufocados pela ordem patrimonial. Novos atores sociais surgiram no cenário da vida urbana que, nas primeiras décadas do século xx, se viu alterada pela crescente industrialização e intensificação da imigração européia. Identificamos empresários, intelectuais, editores e militares, muitos dos quais recrutados nas camadas médias. Alguns destes segmentos, vislumbrando possibilidades de mudanças, instigaram - ainda que tímida e encapuçada - a rebelião das massas. Assim - no mosaico das doutrinas "exóticas" composto pelo anarquismo, pelo socialismo e pelo comunismo - surgiram as primeiras propostas de rebeldia por parte dessa classe média emergente, do operariado e da juventude militar. Este fenômeno - ainda que contido pelo Estado que agia através da decretação de estados de sítios, leis de censura e expulsão - possibilitou a formação do movimento operário ${ }^{421}$, a organização do sindicalismo operário, a rebelião do tenentismo, a formação do PCB - Partido Comunista Brasileiro e a projeção de uma imprensa irreverente, subversiva da ordem conservadora.

\section{Calando a voz operária}

É difícil pensar o estado de agonia vivenciada pela República brasileira sem nos referirmos aos avanços e recuos do movimento operário, enquanto energia

\footnotetext{
${ }^{420}$ FERNANDES, Florestan - A Revolução Burguesa no Brasil. Rio de Janeiro: Zahar, 1975, p. 35.

${ }^{421}$ Importante ressaltar a classe operária brasileira carece de uma memória que, em grande parte, se faz fragmentada, exprimindo as descontinuidades de luta do próprio movimento e do desinteresse das organizações em perpetuar sua história. Essa pobreza de memória - se assim preferirmos expressa a má formação da própria composição dessa classe operária, produto da imigração,da abolição da escravatura, do êxodo rural e das práticas autoritárias gerenciadas pelo Estado. A pobreza de memória tem, também, a ver com a cultura operária (não apenas a brasileira, mas a latino-americana) distintas por sua diversidade, riqueza, pobreza, suas formas e geografia.
} 
política e elemento de contestação e resistência. A ação revolucionária das massas se presta, em determinados momentos, como termômetro para aferirmos o pulsar da República. Se o estudo objetivo da história do operariado tem por objeto o comportamento humano, não devemos deixar de avaliar como se processaram as relações sociais entre patrões e operários tendo em vista a força dos mitos políticos: o mito do consenso, o mito da conspiração judaico-comunista internacional, o mito da democracia racial, o mito do salvador ${ }^{422}$.

Considerando que a ação do homem se situa no contexto humano em um ambiente construido por ele e que seus atos sempre são mais do que simples movimentos - retomando aqui as reflexões de Jean-Pierre Vernant, em Entre Mitos E Política - procuraremos valorizá-los enquanto manifestação de uma atividade mental que deixaram vestígios materiais ${ }^{423}$. O operariado, neste caso, deixou de suas idéias e atos registrados em um conjunto de obras, expressão dos seus conteúdos espirituais. Daí valorizarmos as gráficas e a imprensa operária clandestinas, os impressos produzidos por seus militantes políticos (homens e mulheres) e seus eventos culturais e políticos enquanto estratégias de militância e resistência ${ }^{424}$.

A história do movimento operário brasileiro enquanto fenômeno político está diretamente ligada a presença do estrangeiro no Brasil principalmente italianos, portugueses e espanhóis que, em grande parte, eram camponeses nos seus países de origem ${ }^{425}$. Como partidários do anarcosindicalismo, muitos destes homens dominaram a ideologia e a liderança do movimento tornando-se fonte de energia da fase inicial e, também, uma das causas do seu enfraquecimento. A participação dos italianos na composição do operariado brasileiro foi fundamental, considerando-se sua marcante presença física e experiência política vivenciada nas suas comunidades de origem. Antonio Picarollo, proeminente intelectual socialista nascido na Itália, dizia em 1913 que, ao chegar em São Paulo, "tinha-se a impressão

${ }^{422}$ GIRADET, Raoul - Mitos e Mitologias Políticas. São Paulo: Companhia das Letras, 1982; WIAZOWSKI, Taciana - O Mito da Conspiração Judaico-Comunista: Gênese, Difusão, Desdobramentos, 1907-1954. São Paulo: Associação Editorial Humanitas; Imprensa Oficial; Fapesp, no prelo.

${ }^{423}$ VERNANT, Jean-Pierre - Entre Mitos E Política. São Paulo: EDUSP, 2001, p. 140-141.

${ }^{424} \mathrm{O}$ foco de nossa atenção está voltado para o Rio de Janeiro, Santos e São Paulo, os grandes centros da indústria, do comércio e do sindicalismo na primeira metade do século xx. São Paulo, além de concentrar o maior número de imigrantes vindos da Europa, contava com um governo estadual que liberava subsídios à imigração.

${ }^{425}$ MARAM, Sheldon Leslie - Anarquistas, Imigrantes e o Movimento Operário Brasileiro, 1890-1920. Rio de Janeiro: Paz e Terra, 1979. 
de estar na Itália de além-mar, para onde, juntamente com a língua, são transportados os costumes, as tradições domésticas, as festas populares, tudo enfim..."²6.

Os portugueses, por sua vez, provenientes da zona rural do norte de Portugal, concentraram-se muito mais no Rio de Janeiro e Santos, transformando-se - como os demais imigrantes europeus - no suporte principal da força de trabalho em substituição ao negro escravo que, agora homem livre, não encontrava oportunidades junto ao mundo republicano tolhido por seus preconceitos. Retomamos aqui a crítica de que as elites políticas não haviam incluído os negros em seus projetos nacionais. Comparados aos negros, os trabalhadores europeus eram considerados como superiores em todos os sentidos: enquanto força-motriz para o progresso, símbolo do homem trabalhador, ambiciosos e mais adaptáveis à vida urbana que o próprio brasileiro (ainda que eles fossem considerados como ignorantes, fatalísticos e retrógrados pelas elites dos seus países de origem).

A elite intelectual brasileira encarregou-se de justificar o contraste racial e cultural entre negros ex-escravos e brancos europeus. Jogados em um ambiente urbano confuso e sem a proteção paternalista dos fazendeiros e senhores de engenho, o negro não tinha condições para competir. Mesmo porque o racismo existente no País, nem suas parcas economias, lhes ofereciam oportunidades de trabalho e subsistência. Vale também ressaltar que o estado de espírito de um imigrante recém-chegado diferenciava-se da visão de mundo do ex-escravo (o que é natural, considerando-se suas experiências de vida): o imigrante entrava no Brasil com o intuito de fazer a América, investir suas economias, melhorar sua situação econômica e voltar para a sua terra natal gozando de um estilo e vida que anteriormente lhe havia sido negado na Europa. Os ex-escravos viam a sua emancipação como um meio de libertação do trabalho árduo, enquanto que suas economias (que nem chegavam a tanto) se prestavam apenas para o consumo imediato. De um lado os europeus eram recebidos com generosidade e confiança, tendo a seu favor o meio que lhes garantia o êxito, o estímulo ao amor-próprio e alternativas para o sucesso. Ainda que muitas destas "ofertas" funcionassem como "ilusões" (propaganda enganosa) para arregimentar mão de obra na Europa. Enquanto isso, os negros eram tratados com desprezo sendo esmagado pela roda viva que Oscar Lewis denominou de "cultura da pobreza".

${ }^{426}$ PICAROLLO, António - O Estado de S. Paulo, 29 de Janeiro de 1913, p. 3. 
Os bairros da Mooca, Brás, Bexiga e Bom Retiro transformaram-se nos principais pontos de concentração destes operários imigrantes que dividiam-se entre si de acordo com a sua comunidade de origem. O regionalismo que afligia a Itália, por exemplo, estendeu-se aos trabalhadores italianos em São Paulo, dificultando a sua composição política. Italianos opunham-se aos portugueses por considerá-los como "furadores de greve sem consciência social", além da versão coerente de que os portugueses eram menos preparados que os italianos, razão pela qual lhes dificultavam o aceso aos sindicatos. Em 1912, os imigrantes constituiam a maioria dos empregados na Companhia das Docas de Santos, cujo porto ficou conhecido pela alcunha de "Barcelona do Brasil" e o "O Porto Vermelho", dado o grau de periculosidade política atribuído aos comunistas ali concentrados ${ }^{427}$.

\section{A imprensa rebelde}

Amordaçada pela República, a imprensa dita "revolucionária" se viu forçada a circular na clandestinidade por força da censura institucional. Sua trajetória, cujos meandros nem sempre são fáceis de descobrir, pode ser comparada ao traçado de um labirinto cujas entradas e saídas se encontram ora interrompidas, ora abertas para o mundo múltiplo da resistência ${ }^{428}$. Esta imprensa desempenhou importante papel na organização do operariado brasileiro conscientizando-o das suas possibilidades de ação enquanto agente social e como classe. Daí os jornais não terem um sentido estático, fixo. Eles são, assim como os livros, "investidos de significações plurais e móveis, que se constroem no encontro de uma proposição com um recepção".

${ }^{427}$ TAVARES, Rodrigo Rodrigues - O Porto Vermelbo. A Maré Revolucionária. Inventário DEOPS. São Paulo: Imprensa Oficial; Arquivo Público do Estado, 2001; Idem - A "Moscouzinha Vermelha". São Paulo: Imprensa Oficial; Associação Editorial Humanitas; Fapesp PROIN, 2007.

${ }^{428}$ Parte desta memória pode ser reconstituída através dos jornais confiscados pelo DEOPS/SP, a POlícia Política de São Paulo que, no seu conjunto, se prestam como mostruário dos diferentes segmentos políticos que atuaram no Brasil entre 1924-1983. Cruzados com os registros policiais, estes periódicos nos oferecem a oportunidade de reconstituir as estratégias de ação dos grupos da resistência e a lógica que regia o aparato repressivo estatal. Nos permitem também repensar: o papel do Estado republicano que, ao longo da sua trajetória, amordaçou a imprensa contestatória; as relações da Maçonaria com o movimento anti-fascista e o lugar do impresso no processo de conscientização política nacional. 
Instigou a rebeldia minando, lentamente, a apatia almejada pelas elites políticas. Foi este jornalismo que, vazando a censura institucional, manteve o operário brasileiro ao par das transformações que ocorriam no mundo do trabalho na Europa e nos países da América ${ }^{429}$. Em texto e imagem, o jornalismo político denunciou as injustiças do Estado republicano dedicado a calar a voz dos rebeldes. Abriu espaço aos escritores anônimos rompendo com os preconceitos de cor, gênero, classe e religião. Mobilizou - numa frente única em prol dos direitos humanos - estudantes, operários, intelectuais, artistas plásticos, músicos, caricaturistas e editores, dentre outros. Denunciou a podridão das prisões brasileiras, o sistema editorial a serviço das oligarquias agrárias, a inadimplência das autoridades policiais, a desobediência às leis trabalhistas, a expulsão de estrangeiros e a censura oficial. Publicou as postulações do sindicalismo operário multiplicando as informações sobre os direitos sociais, muitas vezes ignorados pelos trabalhadores seduzidos pelas ações nacionalistas do Estado.

Editados em diferentes idiomas e representando múltiplas ideologias, os jornais ditos "subversivos" eram apreendidos como provas comprometedoras do crime político, de acordo com a lógica da desconfiança adotada pelas autoridades policiais. Uma palavra ou uma imagem eram suficientes para transformar aquelas páginas de papel em manuais de revolução. Sobre os seus produtores, interpretados como mentores intelectuais do crime - corpo editorial, jornalistas, caricaturistas e colaboradores — recaía a culpa pela infração: eles haviam ultrapassado os limites do permitido. Se reincidentes transformavam-se em "reféns do seu próprio passado", distinção formal decorrente do estigma da criminalização, do labelling approach ou teoria do etiquetamento ${ }^{430}$.

O jornal sempre se apresentou como alternativa eficaz de propaganda política. Adotado por todos os segmentos sociais desde a primeira década do século XIX, o jornal se pode ser considerado como um dos mais importantes registros da memória republicana brasileira. Alguns deles inscreveram-se numa tradição de imprensa liberal e revolucionária; outros emergiram como tipicamente antilu-

\footnotetext{
${ }^{429}$ Sintonizado com a política internacional ofereceu-lhe detalhes sobre o cotidiano da Revolução Russa (1917), o genocídio dos armênios (1915), a Guerra Civil Espanhola (1936-1939), o recrudescimento do anti-semitismo na Europa, o Holocausto (1933-1945), a partilha da Palestina (1947) etc. Protestou contra os avanços do nazismo na Alemanha, o fascismo na Itália e o perigo das armas atômicas.

${ }^{430}$ Sobre estes conceitos ver BRISSOLI FILHO, Francisco - Estigmas da Criminalização: dos Antecedentes à Reincidência Criminal. Florianópolis: Editora Obra Jurídica, 1998.
} 
sitanos, nacionalistas ao extremo e, até mesmo, anticlericais. A partir das últimas décadas do século XIX surgiram jornais expressivos dos movimentos negro, anarquista, operário, sindicalista, comunista e anti-fascista ${ }^{431}$.

O confisco de jornais "revolucionários" no Brasil tem suas raízes nos tempos imperiais que nos remetem a dois marcos históricos: a fundação da Imprensa Régia no Rio de Janeiro em 13 de Maio de 1808 e a imediata transformação do Desembargo do Paço em órgão censor no Brasil, conforme decreto assinado por D. João VI em 27 de Setembro daquele mesmo ano ${ }^{432}$. Avaliando a documentação produzida e arquivada pela Polícia percebemos que a repressão contra os jornais militantes se processou em diferentes fases, formas e intensidades:

$1^{a}$ fase (1808-1924): quando o confisco dos jornais esteve sob a responsabilidade da Intendência da Polícia do Rio de Janeiro. Nesta fase detectamos a gênese do jornalismo político militante, inicialmente porta-vOz de propostas reformistas republicanas e que, nas últimas décadas do século XIX, somou forças com outros segmentos defensores da revolução social. A partir de 1907, com a promulgação de duas leis de expulsão — o Decreto no 1641, de 7 de Janeiro de 1907 e o Decreto no 4247, de 6 de Janeiro de 1921 — o Estado instrumentalizou-se de forma a inibir a ação dos militantes estrangeiros em território nacional, ato que atingiu inúmeros editores, jornalistas e tipógrafos envolvidos com o movimento operário, anarquista e anti-fascista ${ }^{433}$.

$2^{a}$ fase (1924-1983): quando, a polícia de São Paulo foi reorganizada pela Lei no 2.034, de 30 de Dezembro de 1924, criando e subordinando a Delegacia de Ordem Polícia e Social ao Gabinete de Investigações e Capturas. Sob o olhar e ação vigilante do Deops ficou, dentre outros segmentos da resistência, o periodismo dito "revolucionário". O auge do confisco aos periódicos ditos de esquerda ocorreu durante as ditaduras de Getúlio Vargas (1930-1945) e Militar (1964-1978).

${ }^{431}$ Como exemplo temos os casos dos jornais A Offensiva, criado e dirigido por Plínio Salgado, em circulação entre Maio de 1934 a Março de 1938; O Integralista, Orgão da Ação Integralista em São Paulo. Cf. Pront. n 1583, Ação Integralista. DEOPS/SP. AESP.

${ }^{432}$ Sobre o Decreto de 27 de Setembro de 1808 ver IPANEMA, Marcelo de - A Censura no Brasil: 1808-1821. Rio de Janeiro: Gráfica Editora Amora, 1949, p. 17 apud ALGRANTI, Leila Mezan - "Política, Religião e Moralidade; A Censura de Livros no Brasil de D. João VI (1808-1921)". In CARNEIRO, Maria Luiza Tucci (org.) - Minorias Silenciadas. História da Censura no Brasil. São Paulo: Edusp; Fapesp, 2002, pp. 103-195.

${ }^{43}$ RIBEIRO, Mariana Cardoso - Venha o Decreto de Expulsão. A Legitimação da Ordem Autoritária no Governo Vargas, 1930-1945. Dissertação de Mestrado em História Social, FFLCH, 2000; BASTOS, José Tavares - Expulsão de Estrangeiros. Paraná: Plácido e Silva, 1924; FARIA, Antonio Bento de - Sob o Direito de Expulsão. Rio de Janeiro: Jacintho Ribeiro dos Santos Editor, 1929; ALMEIDA, Francisco de Paula Lacerda de - Expulsão de Estrangeiros do Território Nacional. Rio de Janeiro: Revista dos Tribunais, 1938. 
Em ambas as fases, a Polícia Política criou um aparato de regras, técnicas de observação e métodos de inspeção semelhantes àqueles empregados pela polícia francesa no século XVII e XVIII ${ }^{434}$. Estes métodos foram sendo aprimorados a partir do final do século XIX e no decorrer do Xx à medida que crescia o temor às revoltas populares. Dedicada a manter a "pacificação interna", a moderna polícia brasileira voltou seu olhar vigilante para os jornais e jornalistas rebeldes avaliados como um dos múltiplos pontos produtores de tensão.

O jornalismo político militante que aflorou nas últimas décadas do século XIX identificava-se, cada vez mais, por seu discurso radical que reinvidicava medidas revolucionárias. Neste contexto, a imprensa anarquista ocupou espaço graças à presença de estrangeiros que, numa primeira fase, lançaram-se como editores. Estes intelectuais garantiam a circulação de uma imprensa irreverente, popular e regional, modelada por idéias socialistas, pela propaganda sindical e anarquista. Plurifacetada circulou pelo Rio de Janeiro, São Paulo, Bahia, Pernambuco, Maranhão e Rio Grande do Norte somando forças ao já existente jornalismo anti-monárquico, pró-federalista, abolicionista e republicano ${ }^{435}$.

Em 1893 o Correio Paulistano anunciava a presença de perigosos anarquistas em São Paulo, avaliados como chefes e partidários dessa "terrível seita destruidora... para no final das contas virem aqui implantar a desordem e uma luta fraticida incompatíveis com a abundância e excelência dos nossos recursos de vida” ${ }^{\star 36}$. A grau de periculosidade atribuído ao movimento libertário aumentava à medida que proliferavam os jornais anarquistas dedicados a denunciar os maus tratos na fazenda, o trabalho de menores nas fábricas, o baixo nível dos salários e as condições de insalubridade das fábricas. Nesta última década do século XIX surgiram os jornais Gli Chiavi Bianchi (1892); L'Operário (1898); L'Asino Umano (1894). La Birichino (1896); L'Avvenire (1894); L'Azione Anarchica, 1900; O Libertário (1898) e A Lanterna (1901) ${ }^{437}$.

${ }^{434}$ ROCHE, Daniel - "A Censura e a Indústria Editorial”. In DARNTON, Robert; ROCHE, Daniel (orgs.) - Revolução Impressa. A Imprensa na França (1875-1899).São Paulo: Edusp, 1996, p. 35.

${ }^{435}$ BAHIA, Juarez - Jornal, História e Técnica. História da Imprensa Brasileira. 4ª ed. ampliada. São Paulo: Ática, 1990, p. 151.

${ }^{436}$ Correio Paulistano, 1893.

${ }^{437}$ RODRIGUES, Edgar - Socialismo e Sindicalismo no Brasil. Rio de Janeiro: Laemmert 1969, p. 64. 
Foi no Estado de São Paulo que o jornalismo militante de esquerda proliferou desequilibrando a "ordem instituída". A capital — principal pólo industrial e núcleo de concentração de imigrantes — não tardou a liderar este gênero de publicação contando com 149 títulos entre 1890-1920, dos quais 53 eram editados em língua estrangeira. As sedes de redação dos jornais "subversivos" multiplicaram-se pelos bairros preferidos pelos imigrantes e operariado em geral, dentre os quais estavam o Bixiga, Barra Funda, Brás, Móoca, Bom Retiro e Vila Zelina.

Identificando os percursos trilhados por estes jornais - do porto para a cidade, da capital para o interior ou da cidade para o campo - estaremos pontuando as comunidades de leitores distintas por sua identidade étnica, nacional ou ideológica. Sem jornaleiro para anunciar qualquer edição extraordinária, estes jornais invadiram todos os tipos de residências onde foram lidos por todas as classes, sem exceção: leitores curiosos, leitores pervertidos, leitores malditos. É raro quem não tenha experimentado, um dia, o sabor de uma leitura proibida!

Seguindo os trilhos de ferro, a "revolução impressa" foi levada, às escondidas, até as cidadezinhas do interior do Estado, rompendo o sossêgo das ilustres autoridades locais. Incomodaram, certamente, padres, coronéis e fazendeiros acostumados ao mando, por tradição. Discursos anarquistas, comunistas, socialistas e anti-fascistas foram lidos e ouvidos pelos pacatos (mas nem tanto) habitantes de São José do Rio Preto, Cosmorama, Bauru, Taquaritinga, Ariranha, Bastos, Catanduva, Santa Adélia, Barretos, Piracicaba, São José do Rio Pardo, Taubaté etc. ${ }^{438}$. Sem respeitar porteiras, mata-burros, pastos e córregos, estes jornais invadiram as fazendas como se fossem pragas incontroláveis. Se para os fazendeiros, os jornais eram "ervas daninhas", para os partidos políticos eles funcionavam como "adubos para fazer a revolução crescer". Mas, os jornais da esquerda militante não estavam sozinhos nesta cruzada política que clamava pelos ideais de Liberdade e Justiça.

Os periódicos integralistas assim como os católicos, também procuravam garantir suas praças de leitores dispostos a empunhar a bandeira em nome de Deus, Pátria e Fámília. Livres de qualquer suspeita, estes jornais circulavam garantidos pelo poder local (conservador e católico, por tradição) dedicados

${ }^{438}$ Ver BRUSANTIN, Beatriz - Na Bôca do Sertão. Módulo Geopolítica do Contrôle. Série Inventário Deops. São Paulo, Arquivo Público do Estado de São Paulo. São Paulo: Imprensa Oficial, 2003. 
a enfrentar o Anti-Cristo, personagem simbólico identificado com os males da modernidade: Liberalismo, Maçonaria, Judaísmo e Comunismo ${ }^{439}$. O confisco de jornais integralistas em 1935, dentre os quais o A Offensiva e O Integralista, teve muito mais um sentido preventivo do que punitivo, postura que não se aplicava aos jornais representantes das "ideológias exóticas". A apreensão do no 38 do A Offensiva - que circulou entre Maio de 1934 a Março de 1938 - se deu em decorrência da publicação de uma matéria na qual Plínio Salgado se vangloriva do triunfo das idéias integralistas na Lei de Segurança Nacional. A disputa era pela "autoria"e não pela crítica aos atos autoritários do governo Vargas que, assim como Plínio Salgado, identificava-se com o ideário dos regimes fascistas europeus ${ }^{440}$.

Para a Polícia Política, o "perigo"não estava em quem vestia camisa verde ou batina preta, e sim naqueles que portavam bandeira vermelha, foice, martelo ou enxada. A força policial ficava a disposição da Igreja Católica para que esta assegurasse a soberania de sua fé sobre as outras igrejas. Assim, até o final do Estado Novo, imperou o "abaixo a toda e qualquer manifestação anti-clerical", postura sustentada tanto pelos anarquistas como pelos comunistas, em geral. Segundo o pesquisador Eduardo Góes de Castro, os Testemunhas de Jeová (Sociedade Torre de Vigia) foram incluídos nesta onda de repressão aos "hereges da Fé" quando da distribuição de Fascismo ou Liberdade que, em Agosto de 1939, teve 20000 exemplares confiscados. Esta situação somente começou a ser alterada durante o Governo do general Eurico Gaspar Dutra quando este, em clima de redemocratização, emitiu o Despacho de 30 de Junho de 1948 que colocava a Igreja Católica na condição de "desrespeito ao culto alheio, perturbando o culto de uma outra religião..." ${ }^{441}$.

439 CARNEIRO, Maria Luiza Tucci - O Veneno da Serpente. Questões Acerca do Anti-semitismo no Brasil. São Paulo: Perspectiva, 2003.

${ }^{440}$ Pront. $n^{\circ} 1583$, Acção Integralista. DEOPS/SP. APESP.

${ }^{441}$ Pront. no 43707, Sociedade Torre de Vigia. DEOPS/SP. APESP. Ver CASTRO, Eduardo Góes de - Os "Quebra Santos". Repressão ao Anticlericalismo no Brasil República (1924-1945). Inventário Deops. São Paulo: Associação Editorial Humanitas; Imprensa Oficial; Fapesp, 2007. 


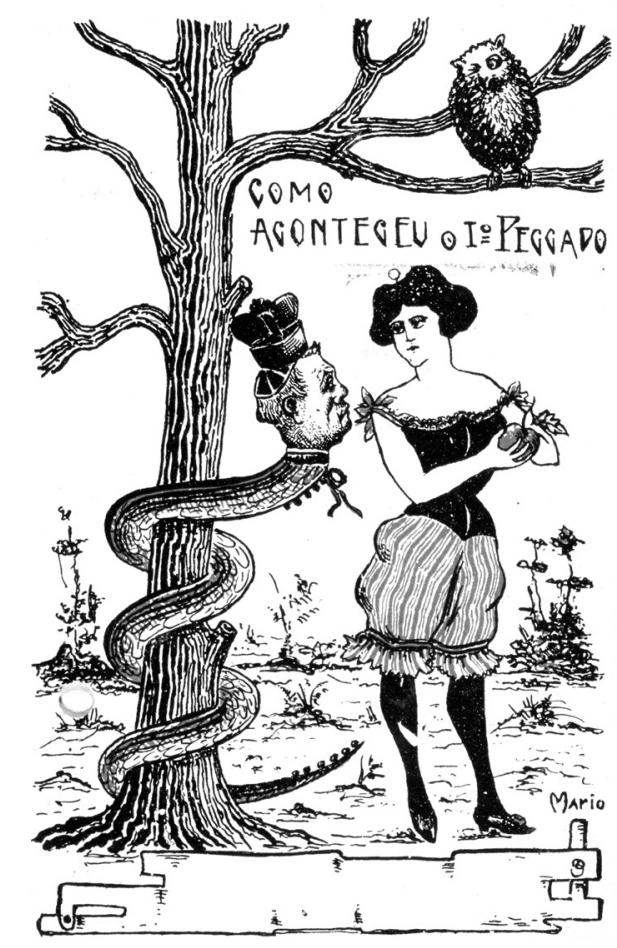

Postal anti-clerical confiscado pela Polícia

Política Brasileira. Pront. $n^{\circ}$ 26. DEOPS/SP. APESP.

O jornalismo irreverente

Ao longo da primeira metade do século xx, a República brasileira se viu fragilizada nos seus ideais liberais. Truncada pela ordem patrimonial, a sociedade encontrava dificuldades para fazer valer suas postulações por direitos sociais. Mas foi graças à ação de um jornalismo irreverente que o "fermento revolucionário" do liberalismo conseguiu proliferar entre as camadas mais populares da população. Dificilmente poderemos avaliar a luta de emancipação do trabalhador, da mulher ou do negro no Brasil republicano, se desconsiderarmos a tríade imprensa, sindicato e partido político. É impossível desvincularmos a trajetória da imprensa militante operária da história do anarquismo e da imigração no Brasil. Se cruzarmos os registros históricos constataremos que os primeiros jornais 
deste segmento social foram fundados por imigrantes que, no calor da hora, se transformaram em editores ou jornalistas autoditadas. Comprometidos com a causa da classe operária, estes homens assumiram distintos papéis que, na maioria das vezes, se superpunham ora como organizadores de base e/ou ideólogos, ora como propagandistas. Dependendo da emergência, exerciam a função de tipógrafos, escritores, conferencistas, ilustradores e, até mesmo, distribuidores de jornais.

Intimidados pelas idéias e pela prática libertárias - e, posteriormente pelas idéias comunistas - a elite republicana radicalizou e avançou contra a anarquia. Preocupado com a circulação de idéias sediciosas, o Governo Provisório emitiu, em 23 de Dezembro de 1889, o primeiro decreto de censura que atingiu diretamente a imprensa ${ }^{33}$. Restringia-se a informação, assim como se proibia reuniões políticas que atentassem contra a nova república laica e liberal.

Importante ressaltar que, neste mesmo ano de 1889, 23 países convocados pelo Partido Social-Democrata Alemão reuniam-se em Paris para formar a II Internacional (1889-1923). Dentre as várias decisões aprovadas durante este encontro, várias tiveram repercussão imediata no cotidiano e no imaginário político brasileiros: a adoção do dia 1o de Maio como data de protesto mundial pela jornada de oito horas de trabalho, manifestação consagrada posteriormente como o Dia Internacional do Trabalho. Além de adotar os princípios marxistas da luta de classes e da socialização dos meios de produção, a II Internacional dava independência aos partidos de cada País respeitando suas diferenças internas. Em 1900 e 1919, os comunistas russos chefiados por Lênin se impuseram de forma expressiva até o momento em que, como dissidentes, optaram por fundar a III Internacional em 4 de Março de 1919, com sede em Moscou.

Neste ínterim, em 1890, haviam desembarcado no porto de Santos cerca de 150 italianos provenientes de Gênova e que tinham um sonho em comum: o de fundarem na América Latina a primeira Colônia Socialista Experimental, empreitada conhecida como Colônia Cecília. Estes pioneiros - dentre os quais estavam Francisco Arnaldo Gattai e sua esposa Argia Fagnoni Gattai, avós paternos de Zélia Gattai - vinham em busca do paraíso idealizado por Cárdias, pseudônimo usado pelo Dr. Giovanni Rossi, autor do livreto Il comune in rival al mare, defensor das idéias de Miguel Bakunin e Pedro Kropotkin. Este havia recebido de D. Pedro II, uma propriedade de 300 alqueires de terras localizadas entre Palmeiras e Santa Bárbara, no Paraná. No entanto, a Nova República — recém 
proclamada em 1889 - castrou os sonhos dos pioneiros italianos, seguidores de Cárdias. Os republicanos não conseguiram acompanhar a mentalidade arrojada de D. Pedro II, imperador brasileiro da modernidade que estendeu as mãos à Anarquia. O ideário dos homens da Colônia Cecília esbarrou nos princípios do novo regime que não conseguiu livrar-se da influência da aristocracia cafeeira, defensora da e portadora de valores cristãos. Os sonhos do Dr. Giovanni Rossi viraram cinzas corroídos por taras milenares ${ }^{442}$.

Em decorrência do avanço anarquista e socialista, cada vez mais comprometido com a causa do operariado, o Congresso brasileiro aprovou, em 1903, a primeira lei de expulsão de estrangeiros sob a alegação de que estes colocavam em perigo a segurança nacional e a ordem pública no Brasil ${ }^{443}$. Os anarquistas - estigmatizados pelas autoridades policiais e empresários desde o século XIX eram acusados de "agitadores do ofício pagos por governos estrangeiros", de "fazer manobras subversivas"e "provocar a greve entre os trabalhadores" ${ }^{444}$.

Uma fina lâmina pairou sobre a cabeça dos "subversivos alienígenas" com a publicação do Decreto no 1.641 , a Lei Adolfo Gordo que regularizava a expulsão dos estrangeiros de parte ou de todo o território nacional, ato que instigou a reação da imprensa operária. Em 1923, o Decreto nº 4.743 - conhecido como Lei de Imprensa - cerceou ainda mais o pensamento, a palavra e a ação dos grupos políticos, dentre os quais os anarquistas e os comunistas. Um ano depois, criava-se o DEOPS - Departamento Estadual de Ordem Política e Social de São Paulo, órgão repressor destinado a vigiar os suspeitos e a punir os criminosos políticos.

Nesta época, a "Colônia Cecília" já era coisa do passado, experiência frustrada mas não abandonada pelos anarquistas que se (re)organizavam pelos bairros operários de São Paulo. Como imigrantes ou filhos de imigrantes vivenciavam na pele o "mito do perigo estrangeiro e o dos agitadores profissionais". O Estado republicano havia aprimorado os instrumentos de controle e repressão, combinando a vigilância aos sindicatos e as manifestações operárias. A ordem oficial era para dispersar qualquer tipo de ajuntamento (greve, comício, reuniões

${ }^{442}$ Sobre esta experiência "exótica" nos trópicos brasileiros ver SCHMIDT, Afonso - A Colônia Cecília. São Paulo: Anchieta, 1942.

${ }^{443}$ CARONE, Edgard - O Movimento Operário (1930-1945). São Paulo: Ática, 1991.

${ }^{44}$ DULLES, John W. Foster - Anarquistas e Comunistas no Brasil (1900-1935). Rio de Janeiro: Nova Fronteira, 1977, p. 29. 
partidárias, palestras, bailes etc.) e punir os "desordeiros" com prisões, degredos e deportações. Numa só seqüência vieram a Lei de Repressão ao Anarquismo, de 17 de Janeiro de 1921 e a Lei Celerada de 12 de Agosto de $1927^{445}$.

Neste momento, os anarquistas de São Paulo - e aqui já se encontrava inserida a família Gattai - reuniam-se diariamente com o objetivo de conquistar adeptos junto a classe operária. Protestavam contra o fechamento de sindicatos e clamavam pela livre circulação dos seus jornais impedidos de circular por "atentarem contra o regime". Dentre eles estava o periódico A Plebe criado em 1917 e interrompido em Julho de 1924, ressurgindo apenas em Fevereiro de 1927. Os anarquistas dividiam o foco da repressão e da censura com os comunistas que, desde 1922, atuavam enquanto partido organizado. Esta polarização se fazia mais evidente nos dois pólos industriais brasileiros: Rio de Janeiro e São Paulo. Ambas as frentes procuravam afirmar seus princípios valendo-se de estratégias próprias de propaganda política. Líderes políticos confundiam-se com a vanguarda dos editores de jornais que, apesar da vigilância diária, procuravam imprimir a revolução.

O ano de 1924 pode ser considerado como de repressão a imprensa rebelde ofuscada por uma série de levantes militares ocorridos em São Paulo. O clima de estado de sítio deu margem para que os rebelados imprimissem seus jornais na clandestinidade com o objetivo de informar o povo sobre os verdadeiros motivos do levante armado. Nesta ocasião ocorria também o levante no Rio Grande do Sul liderado por Luís Carlos Prestes e de outros oficiais de várias guarnições. É desta época a publicação do jornal 5 de Julho que circulou ininterrupta e clandestinamente até o final do governo de Arthur Bernardes em 1926. O Serviço Secreto do Dops do Rio de Janeiro chegou a oferecer 50 contos — uma gorda oferta para a época - a quem denunciasse os editores e a tipografia responsável pela impressão. A tirania institucional deu margens a publicação de um outro jornal clandestino cujo título é sintomático: O Libertador, cujo no 1 foi publicado em Assis em 5 de Agosto de 1924, tendo como redator João de Talma. Os números seguintes saíram em Porto Epitácio e o sexto número no sertão maranhense, sendo os dois últimos de responsabilidade de Reis Perdigão e José Pinheiro Machado, respectivamente. Sufocada, a imprensa revolucionária tentava sobreviver ao estado de sítio.

\footnotetext{
${ }^{445}$ Cf. Decretos n 4.269, de 17 de Janeiro de 1921 e Decreto n 5.221, de 12 de Agosto de 1927. Sobre este tema ver AZEVEDO, Rachel de - A Resistência Anarquista. Uma Questão de de Identidade (1927-1937), São Paulo: Arquivo Público do Estado; Imprensa Oficial, 2002, pp. 46-47.
} 


\section{A vanguarda da rebeldia}

O perfil político dos "homens da imprensa revolucionária" devia-se, em parte, a sua origem estrangeira que, além de abrir-lhe espaço junto as principais comunidades de imigrantes radicadas em São Paulo, os mantinha em sintonia com os movimentos políticos internacionais. Muitos destes editores/líderes eram provenientes de países identificados com os movimentos socialista e libertário em curso, tais como Espanha, Itália e Portugal ${ }^{39}$. E estes países, no início do século, apresentavam-se como os principais núcleos propulsores de emigrantes para o Brasil. Por exemplo, entre 1910-1914, entraram no Brasil 485 espanhóis, dos quais 154 radicaram-se em São Paulo ${ }^{446}$.

A inserção dos imigrantes no mundo da política se fez de forma gradativa e com grandes dificuldades, visto que desde a primeira metade do século Xx, persistiu a imagem negativa de que a maioria fazia parte de uma massa de "agitadores alienígenas". As primeiras ligas operárias de caráter sindical surgiram quase ao mesmo tempo das primeiras agremiações de trabalhadores, as Sociedades de Socorro Mútuo, cujas origens datam do final do século XIX. A influência italiana se fez marcante nas organizações fundadas em 1901 na capital paulista, das quais oito, entre 13, tinham nomes italianos. O mesmo aconteceu com os jornais operários, anarquistas e socialistas escritos em língua italiana como, por exemplo, La Giustizia (1879), L'Asino Umano (1894), La Biricchina (1897), Robattiamo il Chiodo (1897), La Nuova Gente (1903), La Battaglia (1901), L'Azione Anárchica (1905), Guerra Sociale (1915), La Difesa (1923) e Il Rissorgimento (1927) ${ }^{447}$.

Os estereótipos do revolucionário russo, do anarquista espanhol, do antifascista italiano e do judeu internacional rondavam o imaginário brasileiro cujos arquétipos eram, em muitos casos, ditados pelos interesses da elite ilustrada. Foi neste contexto - de moralização dos costumes políticos - que surgiu em São Paulo da Liga Nacionalista (1916-1924) dedicada a afastar os maus imigrantes do País ${ }^{448}$. Ainda que ameaçados pelas leis de expulsão, os estrangeiros - tratados

\footnotetext{
${ }^{446}$ KLEIN, Herbert - A Imigração Espanhola no Brasil. São Paulo: Editora Sumaré; Fapesp, 1994, p. 15.

${ }_{447}$ Presença Italiana no Sindicalismo Brasileiro, Catálogo da Exposição Fotográfica e Seminário Temático. São Paulo: Consulado Geral da Itália; Centro Universitário Maria Antonia, 1994.

${ }^{448}$ FAUSTO, Boris - "Imigração e Participação Política na Primeira República: O Caso de São Paulo". In Idem [et. al] - Imigração e Política em São Paulo. São Paulo: Editora Sumaré; Fapesp, 1995, pp. 7-26 (Série Imigração).
} 
como analfabetos e desprovidos de qualquer sentimento nacional - comprovaram que, antes de fazer a América vinham também para mudar o Brasil. Enquanto agentes sociais, ingressaram nas correntes revolucionárias fazendo oposição aberta às oligarquias; ora como editores de jornais, ora como líderes grevistas, escritores, jornalistas, poetas etc.

\section{Representações Proibidas da República}

Representar a Liberdade enquanto algo a ser conquistado "especificava a natureza do desvio", diziam as autoridades da ordem. No entanto, esta era uma causa defendida por todo revolucionário consciente de que deveria dar asas à criatividade e, através de diferentes estratégias políticas, criar condições de emergência para que a liberdade pudesse respirar. Conquistada, deveria conservar os direitos adquiridos em nome desta mesma liberdade”. Mas, não era fácil romper com os padrões da censura republicana atenta à produção dos artistas rebeldes que se negavam a colaborar com o Estado. Durante a primeira metade do século xx, ecos de protestos iconográficos inspirados em imagens e símbolos franceses conseguiram vir à luz rompendo as fronteiras da clandestinidade.

O uso político de alegorias femininas pode ser interpretado como expressão da ruptura política evidenciada pela passagem da Monarquia para República. Até então, a representação girava em torno da figura do rei que, no novo regime, passa a ser identificado com o atraso e o obscurantismo. É na imprensa anarquista que a representação da Liberdade - enquanto figura feminina inspirada na iconografia da Revolução francesa ${ }^{449}$ — se fez mais freqüente. A imagem da "musa libertária" foi, em inúmeros casos, o principal motivo da apreensão do jornal. Enquanto representação e agente política, a mulher incomodava as

${ }^{449} \mathrm{O}$ uso da alegoria feminina remonta à Roma antiga quando a mulher era tida como a representante da liberdade. No imaginário republicano francês, a figura de Marianne, predomina como alegoria cívica presente da Primeira à Terceira República. Possivelmente pelo fato das mulheres terem tido um papel efetivo nos momentos revolucionários de 1779, 1830, 1848, 1871. Observando imagens representativas da tomada da Bastilha em 1789, veremos que as mulheres se destacam na multidão rebelada contra o Antigo Regime. Para o caso do Brasil ver CARVALHO, José Murilo de - A Formação das Almas: O Imaginário da República do Brasil. São Paulo: Companhia das Letras, 2000, p.76; COELHO, Geraldo Mártires - Marianne: Raízes, Tempos e Formas da Alegoria Feminina da República no Pará, 1891-1897; 1910-1912, texto publicado no presente volume. 
classes dirigentes conservadoras interessadas em alimentar o modelo de mulher-mãe, dona do lar. Mulher rebelde - no estilo de algumas anarquistas como Maria Lacerda de Moura, Isabel Cerruti e Luiza Pessanha de Camargo Branco não convinha aos homens do poder ${ }^{139}$.

A figura feminina que aparece estampada na alegoria "A Revolta" ${ }^{\prime 50}$, reproduzida na primeira página do jornal O Trabalhador, de Maio de 1932, inspirou-se na figura alegórica de Marianne, mulher do povo, símbolo da Liberdade e Revolução. Segurando com a mão esquerda uma tocha ardente erguida ao alto, a jovem mulher de túnica branca - aqui símbolo da revolução social — caminha sobre os escombros do passado (Igreja, monarquia, aristocracia, legislaçâo, técnicas absoletas) destruindo os obstáculos do presente. Resplandecente, "ilumina os espaço das consciências proletárias a caminho de um futuro harmonioso onde a IGUALDADE, a FRATERNIDADE e a LIBERDADE não são mais uma promessa, mas uma realidade científica”.

Aliás, esta foi uma das alegorias mais reproduzida pelos jornais e panfletos anarquistas, tendo sido composta em 1932 por Angelo Las Heras, operário que trabalhava em uma fábrica de bebidas. Las Heras foi autuado pelo DEOPS em 1936 e, em sua residência, foram apreendidas diversas obras "subversivas". Neste mesmo ano, Las Heras foi novamente detido porque a censura postal apreendeu um pacote de jornais editados na Espanha e que lhe havia sido remetido para fins de propaganda política. A dimensão do crime praticado por este francês, natural de Algéria, encontra-se registrada nas listas de expulsão de estrangeiros, ainda que esta não chegado a ser efetivada. Em Fevereiro de 1939, foi concedido o pedido de habbeas corpus em seu favor e, em 1940, o Tribunal de Segurança Nacional confirmou a sua absorvição e o arquivamento do processo.

É na luminosidade irradiada pela tocha que se encontrava instalada a ameaça aos "donos do poder" e que, segundo Agulhon, poderia irradiar-se por toda a população "incendiando"as cidades. É o prenúncio de uma Nova Era, identificada em alguns destes jornais confiscados pelo símbolo do sol nascente,

\footnotetext{
${ }^{450}$ Esta mesma representação da "Revolução Social em marcha, na Hespanha" pode ser identificada nos periódicos A Plebe, no 250 (Maio, 1927) e no 22 (Abril, 1933); A Vida, no 50 (Maio, 1928) e O Trabalhador da Light, no 3 (Maio, 1934), O Trabalhador, no 6 (Maio, 1932). Ver CARNEIRO, Maria Luiza Tucci; KOSSOY, Boris (orgs) - A Imprensa Confiscada pelo DEOPS, 1924-1954. São Paulo: Ateliê Editorial; Imprensa Oficial, 2004.
} 
utilizado como evidência da razão e de sentimento em oposição à Antiga Ordem, simbolizada pelas trevas, pelo atraso e pela ignorância.

A mesma tocha sustentada pela jovem "Revolução" reaparece na primeira página do jornal O Trabalhador Têxtil, publicado em São Paulo em comemoração ao $1^{\circ}$ de Maio de 1952. Desta vez, o portador da luz é um trabalhador que irradia força, amor, meditação e esperança. Atrás de sua figura vigorosa, um sol lhe dá calor e vibração. O Dia do Trabalho é apresentado como o "dia em que os construtores de toda a riqueza da terra, fizeram ficar claro que queriam um lugar ao sol..., é o clarim sempre tocando para despertar a consciência dos trabalhadores para que não adormeçam sobre o travesseiro do comodismo". Sol, clarim, luz e trabalho simbolizam na alegoria ("Primeiro de Maio através dos Tempos") os instrumentos de luta do trabalhador brasileiro contra o sangue derramado de seus companheiros de Boston e Chicago, contra o fim da escravidão. Enfim, é o "grito da revolta dos explorados" em prol de um salário justo, da liberdade e justiça social, de amparo à infância e à velhice.

Em distintos momentos, os inimigos do regime republicano, dentre os quais os anarquistas ocupam um lugar privilegiado, confeccionaram charges e caricaturas que ridicularizavam a figura de Marianne. Expressiva desta postura é a charge publicada em 20 de Julho de 1933 pelo jornal A Lanterna, periódico anti-clerical que se anunciava como "uma obra de saneamento social, negando-se a vender sensacionalismo". Apropriando-se do refrão adotado pelo governo provisório liderado por Getúlio Vargas, o autor [L.N] critica as mudanças anunciadas para a nova Era republicana. Nesta alegoria - distinta da francesa onde a mulher é ostentada como virgem e heróina vigora - a figura feminina que simboliza a República emerge através da imagem de uma mulher sensual, prostituida e corrompida. Perseguida por um padre com feições animalescas, é cobiçada como presa útil, assim como a "velha" o foi, crítica sarcástica às negociações da Igreja que, no Governo Vargas, recuperou seu "status" de oficialidade. A idéia que se destaca neste jogo de compromissos morais e polícos, é a de ascensão do poder católico, em detrimentpo das demais religiões, que legalmente encontravam-se excluídas de ação e participação no cenário brasileiro ${ }^{451}$.

${ }^{451}$ A Igreja constituiu-se, nesse momento, em uma importante peça no tabuleiro político, não interessando a Vargas aliená-la do seu projeto. Alceu Amoroso Lima tornou-se figura constante co-representante leigo autorizado pela Igreja; enquanto Gustavo Capanema, homem de confiança da 


\section{"Eles" e a Republica Nova}

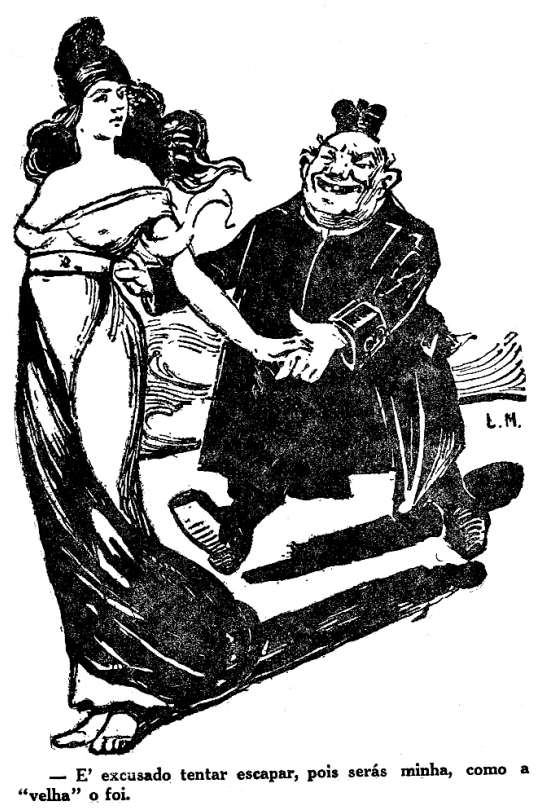

"Eles e a República Nova". A Lanterna,

20 jul. 1933, Ano XI, no 355, p. 4. Anexo

ao Pront. $n^{\circ}$ 1553, A Lanterna, Doc. 4, Fl.4.

Fundo DEOPS/SP. APESP.

A Agonia da República

Nos anos de 1930-1940 assistimos ao desmoronar e à agonia da República brasileira, minada em seus propósitos e traída em seus ideais pelos profissionais do poder. Sob a batuta de Getúlio Vargas, os ideais de liberdade, igualdade e fraternidade foram substituídos pela disciplina do corpo e do espírito, pelo culto

Igreja, foi nomeado para o Ministério da Educação. Expressivas desta aproximação: o Decreto-Lei de 1931 instituindo como obrigatório o ensino religioso nas escolas públicas; e a Constituição de 1934 cujo preâmbulo invoca Deus: "Nós, os representantes do Povo Brasileiro, pondo nossa confiança em Deus....". Ver CARNEIRO, Maria Luiza Tucci - O Anti-semitismo na Era Vargas. Fantasmas de uma geração, 1930-1945. $3^{\text {a }}$ ed. São Paulo: Perspectiva, 2001, pp. 66-68. 
a força e a raça eugênica. Sob o slogan do "nascimento de uma nova Nação" e com o auxílio das Forças Armadas, Vargas instaurou a ditadura, colocando fim à nossa breve e turbulenta experiência democrática de 1934-1937, traindo assim os ideais da Revolução de 30. O signo da Ordem e Progresso continuou a ser reinvidicado pelo poder e conseguido às custas da repressão policial, da domesticação da massa operária e do controle do pensamento. Seduzido pela propaganda oficial estadonovista e fascinado pelas mensagens de progresso, o povo - se perceber - aplaudiu a agonia da República e saiu às ruas para venerar Getúlio, "pai dos pobres".

O golpe de Novembro de 1937 representou o verdadeiro repúdio ao liberalismo político e econômico, consumado com o fechamento do Congresso Nacional, a extinção dos partidos políticos, das eleições e das garantias individuais. Através destes atos autoritários, Getúlio consolidava as propostas em pauta desde Outubro de 1930. Ao outorgar a Constituição de 1937 que conferia plenos poderes ao Presidente da República, Vargas consagrava-se ditador cercado de poderes excepcionais. A nova carta constitucional se fez baseada na centralização política, no intervencionismo estatal e num modelo antiliberal contrariando o modelo liberal clássico de organização da sociedade. As liberdades civis foram suspensas, o Parlamento dissolvido, os partidos políticos extintos, nos moldes das experiências européias mais recentes.

De uma forma geral pairava no ar a idéia de que a "velha democracia liberal" estava em extinção. A Constituição de 1934 passou a ser explicada como "fruto da confusão do momento histórico, enquanto o liberalismo democrático” não se coadunava mais, de maneira alguma, com as aspirações nacionais ${ }^{452}$. Vargas chegou a explicar, logo após o golpe, que esta constituição havia sido "antedatada em relação ao espírito do tempo" ${ }^{\prime 45}$. Apesar de negar qualquer similaridade com os regimes nazi-fascistas, a realidade política sustentada pelo Estado Novo afinava-se com os rumos trilhados pelos países europeus cujos modelos ideológicos serviam de paradigmas para os intelectuais e dirigentes políticos integrados

${ }^{452}$ GALVÃO, F. - Diretrizes do Estado Novo. Rio de Janeiro: DIP, 1942, p. 25-26. Observação: esta publicação mereceu a menção honrosa no concurso de monografia instituído pelo DIP- Departamento de Imprensa e Propaganda, orgão censor do Estado Novo, dirigido por Lourival Fontes.

${ }^{453}$ PANDOLFI, Dulce - "Apresentação". In Idem - Repensando do Estado Novo. São Paulo: Editora FGC, 1999, p. 10. 
ao projeto étnico-político que marcou a chamada Era Vargas. Mesmo assim, diziam-se republicanos:

"Há quem tenha procurado desvirtuar a linha de conduta que traçamos, vendo na expressão Estado Novo um outro regime, senão o mesmo que mantivemos até aqui — o Republicano. Temos usado a expressão Estado Novo Brasileiro, nascida do pensamento do próprio povo - que é soberano na sua escolha para representar com ela uma época de trabalho e de reorganização social..."454.

O nacionalismo alemão transformou-se em fonte de inspiração do que aqui se pretendia construir: um Estado nacional, uniforme e padronizado cultural e politicamente. Esta uniformizaçã implicava na exclusão de grupos estranhos ao projeto de nacionalização e que, de alguma forma, contestassesm o regime imposto. A hora era de recuperação dos mitos estigmatizantes. O tipo germânico tomado como modelo para o homem brasileiro e o regime nazi-fascista idolatrado pelos dirigentes brasileiros, se tornaram, subseqüentemente, metas de homogeneização racial e práxis governamental para o Brasil; situação delicada no momento em que os Estados Unidos cobravam o cumprimento dos ideais democráticos.

Buscando forjar um forte sentimento de identidade nacional, condição essencial para o fortalecimento do Estado nacional, o regime investiu na cultura e na educação. Esta política recaiu contra as áreas de colonização européia, com base nos decretos nacionalistas de 1938, contrariando o ideal de uma sociedade pluralista que abrigasse etnias diversidade. O têrmo eugenia tornou-se comum nos discursos acadêmicos e políticos reproduzindo expressões comumente empregadas pelos nacional-socialistas. Apelou-se para o imaginário coletivo em busca de "quistos raciais". Sob o prisma do fenômeno imigratório, o governo Vargas definiu-se pelo triufo do homem branco, não semita/não judeu.

Fica evidente na documentação produzida por diplomatas e ministros que uma política emigratória aberta à todas etnias entraria em conflito com o ideário político do Estado Novo. Assim, coube aos homens com poder fazer uma seleção arbitrária das significações apresentadas como necessárias à população,

${ }^{454}$ CARRAPETA, S. G. - A Angústia do Século xx e os Problemas Brasileiros. Porto Alegre: Globo, 1941, p. 126-127. 
deferindo a cultura. Através de um discurso nacionalista o povo foi seduzido por mensagens legitimadoras da intolerância, enquanto que à educação coube a tarefa de reforçá-las a longo prazo.

Ao buscar o modelo ideal de homem brasileiro, o Governo Vargas demonstrou que tinha dificuldades em lidar com as diferenças, fossem étnicas ou ideológicas. Daí a sua dedicação à elaboração de um projeto educacional homogeneizador e de uma política emigratória restritiva e seletiva em "prol do abrasileiramento da República". Umas conjuntas de significações imaginárias foram cooptadas de modelos europeus e acionadas como elementos identitários e unificadores da Nação. Após 1937, os sonhos republicanos cairam por terra, fragilizados pelos atos autoritários de Vargas que obstruiu os caminhos que poderiam levar a soberania popular. Procurou, de todas as formas, identificar e eliminar os signos de erosão da identidade cultural brasileira, ou seja, toda e qualquer manifestação de identidade estrangeira.

Contrariava-se mais uma vez, um dos elementos fundamentais do liberalismo que é reconhecimento da diversidade humana. Através de discursos nacionalistas e pseudo-humanitários, o Estado alimentou a imagem superficial de Nação "moderna", herança histórica que merece a atenção dos historiadores e políticos da atual República cujo projeto neoliberal reacende o debate sobre "o legado de Vargas". Não podemos negligenciar a figura de Vargas que, além de articulador político hábil em construir consensos e harmonizar interesses, era também um líder autoritário, assim como o definiu Eli Diniz: “...maquiavélico, especialista na arte de dissimular, de esconder suas reais intenções e manipular as situações a seu favor, emfim, um mestre no emprego da astúcia e da força ao sabor de suas conveniências políticas"'\$55.

Uma das primeiras iniciativas do Estado Novo foi a de investir contra os núcleos estrangeiros nas zonas de colonização. Um conjunto de decretos-lei foram destinados a conter as experiências educacionais que colocassem em risco a campanha de nacionalização e construção da identidade brasileira. Ao mesmo tempo investiu contra os judeus rotulados de estrangeiros "indesejáveis", comunistas, reafirmando princípios anti-semitas seculares. O fechamento de centenas de

\footnotetext{
${ }^{455}$ DINIZ, Eli - "Engenharia institucional e políticas públicas: dos conselhos técnicos às câmaras setoriais". In PANDORFI, Dulce (org.) - op. cit., p. 21.
} 
escolas estrangeiras interrompeu um processo cultural de muitos anos: proibiu-se o ensino em língua estrangeira e os jornais deveriam circular apenas em português. Esta ação repercutiu junto a impressa internacional e, mais diretamente, naqueles países que tinham representatividade no Brasil ${ }^{156}$.

As primeiras iniciativas nesta direção partiram das autoridades estaduais do Paraná que endossaram "medidas rigorosos". No início de 1938 foram assinados decretos que probiam, durante os três primeiros anos, o ensino de línguas estrangeiras nas escolas públicas. Nenhum estabelecimento escolar poderia ser mantido ou subsidiado pelos governos ou entidade estrangeiras. Esta determinação atingia diretamente as escolas rurais polonesas e alemãs, maioria no sul do País. Os poloneses do Paraná, acuados pela repressão policial e pela conseqüente tentativa de desestruturação de sua identidade cultural, manifestaram-se diante do etnocídio do qual estavam sendo vítimas. Aos olhos das autoridades brasileiras, atitudes deste tipo foram rotuladas de "megalomania que, em dado momento de exacervação, pode ter conseqüências sérias". Megalomania aqui traduzida como sendo a "visão obsecada da Polônia de se tornar um império colonial"

A violência foi acionada como instrumento de domínio apoiada por uma base de poder: uma polícia política e seus informantes, atos legais, aparelhos de propaganda, doutrinação e censura. Como muito bem lembrou Hannah Arendt em Crises da República:

"Poder e violência, ainda que fenômenos distintos, quese sempre aparecem juntos. Violência é por natureza instrumental; como todos os meios, sempre necessita de orientação e justificação pelos fins que persegue... e o que necessita de ser justificado por outra crise, não pode ser essência de coisa nenhuma" ${ }^{\text {"358. }}$.

${ }^{456}$ Segundo informou a Gazeta Polska existiam no Brasil em 1938, 275 mil poloneses, dos quais 106 mil possuíam nacionalidade polonesa. O número de escolas era de 326 e o de professores de 352 (184 crianças freqüentavam escolas).

${ }^{457}$ Ofício de J. de A. Figueira de Mello, da Legação dos Estados Unidos do Brasil em Varsóvia para Mário Pimentel Brandão, Ministro das Relações Exteriores. Varsóvia, 3 de Fevereiro de 1938. Missões Diplomáticas Brasileiras, Ofícios Recebidos, 1938, p.1. AHI/RJ.

${ }^{458}$ ARENDT, Hannah - Crises da República. São Paulo: Perspectiva, 1983, p.117, 120. Sobre este assunto ver também CANCELLI, Elizabeth - O Mundo da Violência: A Polícia Na Era Vargas. Brasília: EDUNIB, 1993. 
Ao atacar os poloneses e alemães, o Governo investia também contra os judeus refugiados do nazi-fascismo e que, no Brasil, procuravam recomeçar a vida. Por volta de 1936, as autoridades diplomáticas brasileiras sediadas em Varsóvia, vasculharam - a pedido do Ministério das Relações Exteriores do Brasil - a documentação que lá estava arquivada sobre a emigração polonesa para o País. J. Wojcikowna, auxiliar do Consulado Geral do Brasil, averigou ficha por ficha, arrolando estatísticamente o número de emigrantes poloneses. Constatou que, em 1935, embarcaram 1641 emigrantes sendo 789 judeus e 90 "falsos" judeus agricultores. Dos 73 poloneses que entraram no Brasil durante o mês de Junho, 63 eram judeus" ${ }^{\prime 59}$.

Assim, a República entrou em "estado de agonia" pressionada pela valorização de um Estado forte, intolerante e tutor da sociedade civil. E foi, como tal, que o poder acionou o preconceito racial contra judeus, negros, ciganos e japoneses, alimentando valores e herdados do nosso passado colonial e adormecidos no inconsciente coletivo. Defendeu, através de atos e programas legais, a homogeneidade racial em favor dos arianos, elementos positivos para configuração de uma raça pura, eugênica. Combateu o comunismo que, enquanto inimigo-político foi tratado como "exótico" e assassino. Sob este viés, as elites políticas construiram a imagem do perigo comunista influenciadas pelos paradígmas do fascismo e do dicurso ante-semita vigentes na Europa durante as décadas de 1930-1940. A imagem feminina foi oficialmente reabilitada para representar a Civilização que, desta vez, jaz morta, ensanguentada pelo punhal de um comunista que a golpeia, sem dó, dando asas à imaginação.

\footnotetext{
459 Ofício de Edgardo Barbedo do Consulado Geral do Brasil em Varsóvia para Jorge Latour, Encarregado dos Negócios do Brasil em Varsóvia. Varsóvia, 19 de Outubro de 1936. Missões Diplomáticas Brasileiras, Ofícios Recebidos, out. 36 a 37, p.3. AHI/RJ.
} 


\section{Eis os principios:}

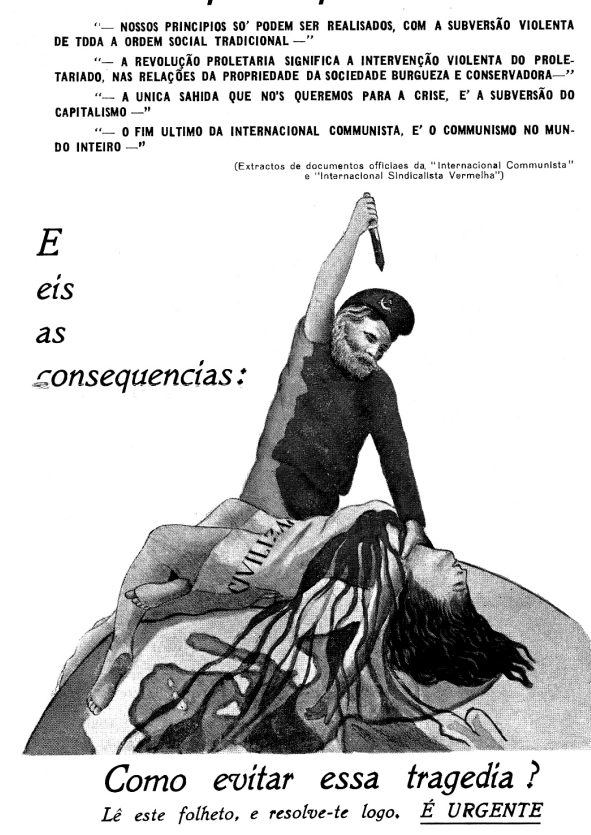

Panfleto "Como evitar esta tragédia",s/d.

Anexado ao Pront.2239, Liga Anticomunista.

DEOPS/SP. AESP

\section{Bibliografia}

ALGRANTI, Leila Mezan - "Política, Religião e Moralidade; A Censura de Livros no Brasil de D. João VI (1808-1921)”. In CARNEIRO, Maria Luiza Tucci (org.) - Minorias Silenciadas. História da Censura no Brasil. São Paulo: Edusp; Fapesp, 2002, pp. 103-195.

ALMEIDA, Francisco de Paula Lacerda de - Expulsão de Estrangeiros do Território Nacional. Rio de Janeiro: Revista dos Tribunais, 1938.

ANDRADE, Mario de - Macunaíuma: O Herói Sem Nenhum Caráter. $25^{\text {a }}$ ed. Belo Horizonte: Itatiaia, 1988 (Coleção Buriti nº 41).

ARENDT, Hannah - Crises da República. São Paulo: Perspectiva, 1983.

AZEVEDO, Rachel de - A Resistência Anarquista. Uma Questão de de Identidade (1927-1937). São Paulo: Arquivo Público do Estado; Imprensa Oficial, 2002. 
BAHIA, Juarez - Jornal, História e Técnica. História da Imprensa Brasileira. $4^{\mathrm{a}}$ ed. ampliada. São Paulo: Ática, 1990.

BASTOS,José Tavares - Expulsão de Estrangeiros. Paraná: Plácido e Silva, 1924.

Os Males do Presente e as Esperanças do Futuro. São Paulo: Companhia Editora Nacional, 1939 (Brasiliana, Vol. 151).

BELlO, José Maria - História da República, 1889-1954. São Paulo: Companhia Editora Nacional, 1972.

BONFIM, Manoel - A América Latina: Males de Origem. Rio de Janeiro: Topbooks, 1993, p. 173, (1. ed. 1903).

BRISSOLI FILHO, Francisco - Estigmas da Criminalização: Dos Antecedentes à Reincidência Criminal. Florianópolis: Editora Obra Jurídica, 1998.

BRUSANTIM, Beatriz - Na Bôca do Sertão. Módulo Geopolitica do Contrôle. Série Inventário Deops. São Paulo: Arquivo Público do Estado de São Paulo; Imprensa Oficial, 2003.

CARNEIRO, Maria Luiza Tucci - Preconceito Racial em Portugal e Brasil Colôni. Os Cristãos-Novos e a Questão da Pureza de Sangue. $3^{\text {a }}$ ed. São Paulo: Perspectiva, 2005. - O Anti-semitismo na Era Vargas. Fantasmas de uma geração, 1930-1945. $3^{\text {a }}$ ed. São Paulo: Perspectiva, 2001. - O Veneno da Serpente Questões Acerca do Anti-semitismo no Brasil. São Paulo: Perspectiva, 2003.

- "Negros Loucos, Loucos Negros". Revista USP. São Paulo, (18), Jul-Ago, 1993, pp. 144-150. - KOSSOY, Boris (orgs), A Imprensa Confiscada pelo DEOPS, 1924-1954. São Paulo: Ateliê Editorial; Imprensa Oficial; 2004.

CARrapetA, S.G. - A Angústia do Século xx e os Problemas Brasileiros. Porto Alegre: Globo, 1941.

CARONE, Edgard - A Primeira República (1889-1930): Texto e Contexto. Rio de Janeiro: DIFEL, 1976. - O Movimento Operário (1930-1945). São Paulo: Ática, 1991.

CARVAlHO, José Murilo de - A Formação das Almas. O Imaginário da República no Brasil. São Paulo: Companhia das Letras, 1990. - Os Bestializados. O Rio de Janeiro e a República que não foi. São Paulo: Companhia das Letras, 1987.

CASTRO, Eduardo Góes de - Os "Quebra Santos". Repressão ao Anticlericalismo no Brasil República (1924-1945). Inventário Deops. São Paulo: Associação Editorial Humanitas; Imprensa Oficial; Fapesp, 2007.

CORTINA, Manuel Suárez - "Las tradiciones culturales del Liberalismo español", in Las Máscaras de la Libertad. El Liberalismo Español, 1808-1950. Madrid: Marcial Pons Historia; Fundación Práxedes Mateo Sagasta, 2003.

DULLES, John W. Foster - Anarquistas e Comunistas no Brasil (1900-1935). Rio de Janeiro: Nova Fronteira, 1977.

FARIA, Antonio Bento de - Sob o Direito de Expulsão. Rio de Janeiro: Jacintho Ribeiro dos Santos Editor, 1929.

FAUSTO, Boris - "Imigração e Participação Política na Primeira República: O Caso de São Paulo". In Idem [et. al], Imigração e Política em São Paulo. São Paulo: Editora Sumaré; Fapesp, 1995, pp. 7-26 (Série Imigração). 
FERNANDES, Florestan - A Revolução Burguesa no Brasil. Rio de Janeiro: Zahar, 1975.

FERNANDES, Jorge Batista - "A Constituinte de 1890-1891. A institucionalização dos limites da cidadania”. Acervo. Revista do Arquivo Nacional, Rio de Janeiro, v.19, no 1-2, Jan/Dez 2006.

FERNANDES, Jorge Batista - "A Constituinte de 1890-1891. A Institucionalização dos Limites da Cidadania”. Acervo. Revista do Arquivo Nacional. Rio de Janeiro (19): 01/02, Jan.-Dez., 2006, pp. 55-68.

GALVÃO, F. - Diretrizes do Estado Novo. Rio de Janeiro: DIP, 1942.

GIRARDET, Raoul - Mitos e Mitologias Políticas. São Paulo: Companhia das Letras, 1982.

KLEIN, Herbert - A Imigração Espanhola no Brasil. São Paulo: Editora Sumaré; Fapesp, 1994.

KOSSOY, Boris - Militão de Azevedo e a Documentação Fotográfica de São Paulo (1862-1887).

Recuperação da Cena Paulistana através da Fotografia. Dissertação de Mestrado em Ciência. Escola Pós-Graduada de Ciências Sociais da Fundação Escola de Sociologia e Política de São Paulo, 1978, p. 87.

MAGALHÃES, Marcelo de Souza Magalhães - "Repensando política e cultura no início da República: existe uma cultura política carioca”. In RACHEL Soihet, Rachel; BICALHO, Maria Fernanda Baptista; GOUVÊA, Maria de Fátima Silva (orgs.), Culturas Políticas. Ensaios de História Cultural, História Política e Ensino de História. Rio de Janeiro: Mauad, 2005, pp.285-303.

MARAM, Sheldon Leslie - Anarquistas, Imigrantes e o Movimento Operário Brasileiro, 1890-1920. Rio de Janeiro: Paz e Terra, 1979.

MARTINS, Ana Luiza - República, Um Outro Olhar. São Paulo: Contexto.

MARTINS, Wilson - História da Inteligência Brasileira. Vol. IV (1877-1896). São Paulo: Cultrix, 1978.

LIMA, Nísia Trindade; HOCHMAN, Gilberto - "Pouca saúde, muita saúva, os males do Brasil são... Discurso Médico-sanitário e interpretação do pais". Ciência E Saúde Coletiva, 5 (2): 313-332, 2000, pp. 313-331.

PANDOLFI, Dulce - Repensando do Estado Novo. São Paulo: Editora FGC, 1999.

PRADO, Maria Emilia - Memorial das Desigualdades: os Impasses da Cidadania no Brasil (1870-1902). Rio de Janeiro: Faperj/Revan, 2005.

Presença Italiana no Sindicalismo Brasileiro, Catálogo da Exposição Fotográfica e Seminário Temático. São Paulo: Consulado Geral da Itália; Centro Universitário Maria Antonia, 1994

RIBEIRO, Mariana Cardoso - Venha o Decreto de Expulsão. A Legitimação da Ordem Autoritária no Governo Vargas, 1930-1945. Dissertação de Mestrado em História Social, FFLCH, 2000.

ROCHE, Daniel - "A Censura e a Indústria Editorial”, in Darnton, Robert; Roche, Daniel (orgs.), Revolução Impressa. A Imprensa na França (1875-1899). São Paulo: Edusp, 1996.

RODRIGUES, Edgar - Socialismo e Sindicalismo no Brasil. Rio de Janeiro: Laemmert, 1969.

ROMERO, Silvio - História da Literatura Brasileira. $5^{\mathrm{a}} \mathrm{ed}$. Rio de Janeiro: José Olympio, 1953.

SACCHETTA, José Ariovaldo Ramos Mendes - Laços de Sangue. Tese de Doutorado em História Social, FFLCH-USP, 2007.

SCHMIDT, Afonso - A Colônia Cecília. São Paulo: Anchieta, 1942.

TAVARES, Rodrigo Rodrigues - O Porto Vermelho. A Maré Revolucionária. Inventário DEOPS. São Paulo: Imprensa Oficial; Arquivo Público do Estado, 2001. 
- A "Moscouzinha Vermelha". São Paulo: Imprensa Oficial; Associação Editorial Humanitas; Fapesp PROIN, 2007.

TEIXEIRA, Múcio - Novos Ideais. Rio de Janeiro: Tipografia (Imprensa) Nacional, 1880; (2a ed. 1891).

VERNANT, Jean-Pierre - Entre Mitos E Política. São Paulo: EDUSP, 2001.

VIANNA, Luiz Werneck - "Caminhos e Descaminhos da revolução Passiva à Brasileira". Dados, Rio de Janeiro, IUPERJ, Vol. 39, n³, 1996. Texto elaborado a partir da transcrição da gravação da conferência de mesmo título.

VIANNA, Oliveira - Raça e Assimilação. São Paulo: Companhia Editora Nacional, 1932 [Coleção Brasiliana].

WIAZOWSKI, Taciana - O Mito da Conspiração Judaico-Comunista: Gênese, Difusão, Desdobramentos, 1907-1954. São Paulo: Associação Editorial Humanitas; Imprensa Oficial; Fapesp, no prelo. 